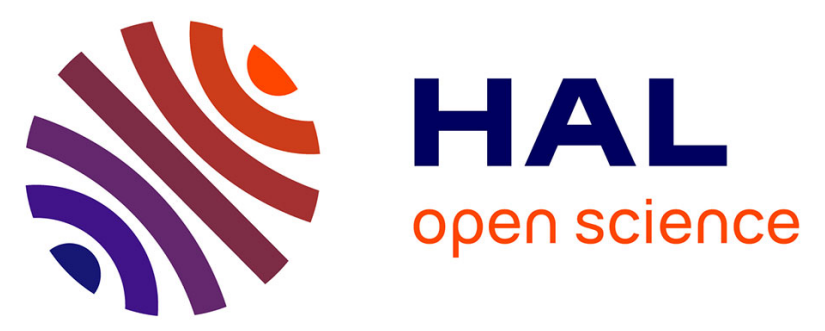

\title{
Ferro- and antiferromagnetic coupling in a chlorido-bridged, tetranuclear $\mathrm{Cu}$ (ii) complex
}

Michael Grosshauser, Peter Comba, Jee Young Kim, Keisuke Ohto, Pierre

Thuéry, Young Hoon Lee, Yang Kim, Jack Harrowfield

\section{- To cite this version:}

Michael Grosshauser, Peter Comba, Jee Young Kim, Keisuke Ohto, Pierre Thuéry, et al.. Ferro- and antiferromagnetic coupling in a chlorido-bridged, tetranuclear $\mathrm{Cu}(\mathrm{ii})$ complex. Dalton Transactions, 2014, 43 (15), pp.5662-5666. 10.1039/c4dt00305e . hal-01157656

\section{HAL Id: hal-01157656 \\ https://hal.science/hal-01157656}

Submitted on 17 Nov 2015

HAL is a multi-disciplinary open access archive for the deposit and dissemination of scientific research documents, whether they are published or not. The documents may come from teaching and research institutions in France or abroad, or from public or private research centers.
L'archive ouverte pluridisciplinaire HAL, est destinée au dépôt et à la diffusion de documents scientifiques de niveau recherche, publiés ou non, émanant des établissements d'enseignement et de recherche français ou étrangers, des laboratoires publics ou privés. 
Cite this: Dalton Trans., 2014, 43, 5662

Received 28th January 2014, Accepted 6th February 2014

DOI: $10.1039 / c 4 d t 00305 e$

www.rsc.org/dalton

\section{Ferro- and antiferromagnetic coupling in a chlorido-bridged, tetranuclear $\mathrm{Cu}\left({ }_{1}\right)$ complex $\uparrow$}

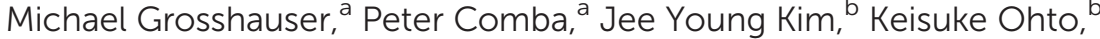 \\ Pierre Thuéry, ${ }^{c}$ Young Hoon Lee, ${ }^{d}$ Yang Kim ${ }^{\star d}$ and Jack Harrowfield ${ }^{e}$
}

A bispidine-like ligand involving four pyridine- $\mathrm{N}$ and three aliphatic- $\mathrm{N}$ donor atoms forms a bimetallic species with $\mathrm{CuCl}_{2}$ in which all seven $\mathrm{N}$-donors are bound and which aggregates in the crystal through double chloride-bridging to give a tetranuclear unit. The magnetism of this solid can be interpreted in terms of a relatively weak antiferromagnetic coupling between the two $\mathrm{Cu}($ (I) centres of the dinuclear subunits and a strong ferromagnetic coupling of the $\mathrm{Cu}(\mathrm{II})$ centres in different dinuclear units involved in the bis-chlorido bridge. In solution, the assembly decays into the dinuclear subunits and, in agreement with the solid state studies, the interaction between the corresponding $\mathrm{Cu}^{\prime \prime}$ centres is shown to be primarily due to dipole-dipole coupling.

\section{Introduction}

The bispidine platform has proven to be extremely useful for the generation of multidentate ligands, in particular ditopic species suited to the formation of both homo- and heterodinuclear complexes in which specific coordination geometries are enforced. ${ }^{1}$ In the case of $\mathrm{Cu}(\mathrm{II})$, the separation of the metal ions in these dinuclear species can be such as to provide useful models of copper oxidase enzymes, especially of intermediate species involving oxygen coordination. ${ }^{2}$ Here, intramolecular bridging of the metal centres by the exogenous (oxygen-derived) ligand may be observed, but it is also known that an exogenous ligand, a cyanide ion, for example, ${ }^{3}$ can cause intermolecular bridging and thus lead to the formation

\footnotetext{
${ }^{a}$ Universität Heidelberg, Anorganisch-Chemisches Institut, INF 270, D-69120 Heidelberg, Germany

${ }^{b}$ Department of Chemistry \& Applied Chemistry, Faculty of Science \& Engineering, Saga University, 1-Honjo, Saga 840-8502, Japan

${ }^{c}$ CEA, IRAMIS, UMR 3299 CEA/CNRS, SIS2M, LCCEf, Bât. 125, 91191 Gif-sur-Yvette, France

${ }^{d}$ Department of Chemistry \& Advanced Materials, Kosin University, 194, Wachi-Ro, Yeongdo-gu, Busan 606-701, South Korea.E-mail: ykim@kosin.ac.kr

${ }^{e}$ ISIS, Université de Strasbourg, 8, allée Gaspard Monge, 67083 Strasbourg, France $\dagger$ Electronic supplementary information (ESI) available. CCDC 979553. For ESI and crystallographic data in CIF or other electronic format see DOI: 10.1039/c4dt00305e
}

of higher aggregates, potentially with interesting magnetic properties. The magnetic properties of ligand-bridged $\mathrm{Cu}(\mathrm{II})$ centres in general have in fact been of interest for a very long time $^{4}$ and their characteristics are known to be sensitive to subtle variations in the co-ligand structure for a given bridge, ${ }^{5}$ with the chloride ion being an especially prominent bridging species. ${ }^{5,6}$ Bispidine-derived oligonuclear complexes are of particular interest in this respect due to the specific and rigid structure of the adamantane-derived ligand backbone. ${ }^{3}$ We report herein the characterisation of the complex of a dinucleating bispidine derivative L (Fig. 1) with copper(II) chloride in which chloride bridging in the solid state leads to the presence of centrosymmetric tetranuclear units having inequivalent inner and outer magnetic centres.

\section{Experimental}

\section{Syntheses}

All reagents were purchased from Aldrich and used without further purification. Chromatography was conducted in glass columns under gravity flow with a SP-Sephadex C25 $\left(\mathrm{Na}^{+}\right.$form) ion exchange resin. Electronic absorption spectra were recorded on a SCINCO S-2100 diode array spectrophotometer and elemental analyses were obtained using a Chemtronics TEA-3000 analyser.

$N^{1}, N^{1}$-Bis(pyridin-2-ylmethyl)ethane-1,2-diamine $\quad(\text { BPEA })^{7}$ and bis(pyridyl)piperidone (BPPO) ${ }^{8}$ (Fig. 1) were prepared using published procedures. BPEA $(2.42 \mathrm{~g}, 10 \mathrm{mmol})$ and aqueous formaldehyde $(37 \%, 1.9 \mathrm{~mL}, 23 \mathrm{mmol})$ were added to a suspension of BPPO $(4.57 \mathrm{~g}, 13 \mathrm{mmol})$ in a $1: 1$ THF-methanol $(50 \mathrm{~mL})$ mixture. The mixture was heated at $70{ }^{\circ} \mathrm{C}$ for $24 \mathrm{~h}$ with stirring under a nitrogen atmosphere. The solvent was removed under reduced pressure to give a black-coloured syrup, which was suspended in methanol $(20 \mathrm{~mL})$ and $\mathrm{CuCl}_{2} \cdot 2 \mathrm{H}_{2} \mathrm{O}(3.75 \mathrm{~g}, 22 \mathrm{mmol}$ in $50 \mathrm{~mL}$ methanol $)$ added. The solvent was removed under reduced pressure and the residue dissolved in water $(200 \mathrm{~mL})$, then absorbed onto SP-Sephadex C25 and eluted with aqueous $\mathrm{NaCl}$ solution $\left(0.3 \mathrm{~mol} \mathrm{~L}^{-1}\right)$. 


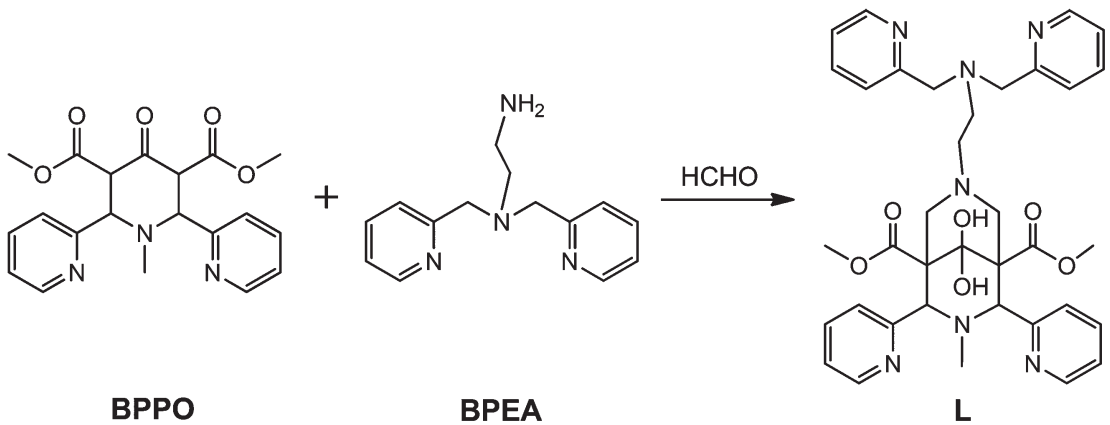

Fig. 1 Synthesis of the bispidine derivative L used in the present work, shown in its carbonyl-hydrate form, from bis(pyridyl)piperidone (BPPO) and bis(pyridyl)diamine (BPEA) precursors.

Three fast-moving minor bands were removed and discarded before the fourth major blue fraction was collected. It was evaporated to dryness under reduced pressure and extracted several times into ethanol to leave $\mathrm{NaCl}$ behind, then evaporated again to give a green powder. Yield, $1.6 \mathrm{~g}$. The complex was dissolved in a minimum volume of methanol and this solution slowly evaporated at ambient temperature after addition of $\mathrm{LiClO}_{4}$ to give the crystals used for the structure determination. Anal. calc. for $\mathrm{C}_{72} \mathrm{H}_{86} \mathrm{Cl}_{8} \mathrm{Cu}_{4} \mathrm{~N}_{14} \mathrm{O}_{30}$ : C, 39.94; H, 4.00; N, 9.06. Found: C 40.1, H 4.11, N 8.87\%. Visible spectrum (in water): $\lambda_{\max } 635 \mathrm{~nm}, \varepsilon_{\max } 152 \mathrm{M}^{-1} \mathrm{~cm}^{-1}$.

\section{Crystallography}

Crystallographic data were collected at $150(2) \mathrm{K}$ on a Nonius Kappa-CCD area-detector diffractometer ${ }^{9}$ using graphitemonochromated Mo K $\alpha$ radiation $(\lambda=0.71073 \AA)$. The crystal was introduced into a glass capillary with a protecting "Paratone-N" oil (Hampton Research) coating. The unit cell parameters were determined from ten frames, then refined on all data. The data (combinations of $\varphi$ - and $\omega$-scans with a minimum redundancy of 4 for $90 \%$ of the reflections) were processed with HKL2000. ${ }^{10}$ Absorption effects were corrected empirically with the program SCALEPACK. ${ }^{10}$ The structure was solved by direct methods and refined by full-matrix leastsquares on $F^{2}$ with SHELXTL. ${ }^{11}$ All non-hydrogen atoms were refined with anisotropic displacement parameters. One perchlorate ion (containing $\mathrm{Cl} 4$ ) is disordered over two positions sharing two oxygen atoms, while another one (Cl5) has a twofold rotation axis of symmetry. The hydrogen atoms bound to oxygen atoms were found on a Fourier-difference map and the carbon-bound hydrogen atoms were introduced at calculated positions; all were treated as riding atoms with an isotropic displacement parameter equal to 1.2 times that of the parent atom (1.5 for $\mathrm{CH}_{3}$ ).

Crystal data for $\left[\mathrm{Cu}_{4} \mathrm{~L}_{2} \mathrm{Cl}_{4}\right]\left(\mathrm{ClO}_{4}\right)_{4} \cdot 2 \mathrm{H}_{2} \mathrm{O}: \mathrm{C}_{72} \mathrm{H}_{86} \mathrm{Cl}_{8}$ $\mathrm{Cu}_{4} \mathrm{~N}_{14} \mathrm{O}_{30}, M=2165.31$, monoclinic, space group $C 2 / c, a=$ 23.3110(15), $b=8.0645(4), c=44.562(3) \AA$ A, $\beta=92.994(6)^{\circ}, V=$ 8365.9(9) $\AA^{3}, Z=4$. Refinement of 594 parameters on 7875 independent reflections out of 71127 measured reflections $\left(R_{\text {int }}=0.106\right)$ led to $R_{1}=0.068, \mathrm{w} R_{2}=0.196, \Delta \rho_{\text {min }}=-0.71$,

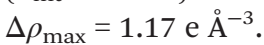

\section{EPR and magnetic susceptibility measurements}

Continuous-wave X-band EPR spectra (ca. $9 \mathrm{GHz}$ ) were recorded on a Bruker Biospin ELEXSYS E500 spectrometer with a Super High Q cavity. A flow-through cryostat in conjunction with a Eurotherm (B-VT-2000) variable-temperature controller was used to provide liquid nitrogen temperatures. The microwave frequency and magnetic field were calibrated with a Bruker frequency counter and an ER041XK Teslameter. The simulated and experimental spectra were visualized with Bruker's Xepr software suite. The mono- and dinuclear complexes were simulated with the computer simulation software package XSophe. ${ }^{12}$

Magnetic measurements were carried out on a MPMS-XL 5 T (Quantum Design) SQUID magnetometer. Samples were powdered and pressed in PTFE tape to avoid field-induced orientation. Data were corrected for diamagnetism of the sample holder, and Pascal's constants were used for diamagnetic corrections of the sample. ${ }^{13}$ For the simulation of the susceptibility plot, the program julX was used. ${ }^{14}$ The Hamiltonian used was:

$$
\begin{aligned}
H= & -2 \sum_{i=1}^{\mathrm{ns}-1} \sum_{j=i+1}^{\mathrm{ns}} J_{i j} \vec{S}_{1} \cdot \vec{S}_{j} \\
& +\sum_{i=1}^{\mathrm{ns}} D_{i}\left[S_{z, i}^{2}-\frac{1}{3}\left(S_{i}+1\right)+\frac{E_{i}}{D_{i}}\left(S_{x, i}^{2}-S_{y, i}^{2}\right)\right]+\sum_{i=1}^{\mathrm{ns}} g \beta \vec{S}_{i} \cdot \vec{B}
\end{aligned}
$$

\section{Results and discussion}

\section{Synthesis}

The versatility of the bispidine pathway to multidentate ligand fabrication $^{1}$ is further illustrated by the present work, although the basic chemistry itself is, of course, familiar. Formation of the $\mathrm{Cu}(\mathrm{II})$ complex and its chromatography on a cation exchange column provides a convenient means of purifying the viscous and involatile crude ligand reaction product.

\section{Crystallography}

The crystal lattice of $\left[\mathrm{Cu}_{4} \mathrm{~L}_{2} \mathrm{Cl}_{4}\right]\left(\mathrm{ClO}_{4}\right)_{4} \cdot 2 \mathrm{H}_{2} \mathrm{O}$ can be regarded as comprising sheets of centrosymmetric tetranuclear cations, $\left[\mathrm{Cu}_{4} \mathrm{~L}_{2} \mathrm{Cl}_{4}\right]^{4+}$ (Fig. 2; Table 1), separated by sheets of perchlorate anions and water molecules, these sheets lying parallel to the $b c$ plane. This separation of the cation sheets is such as to 


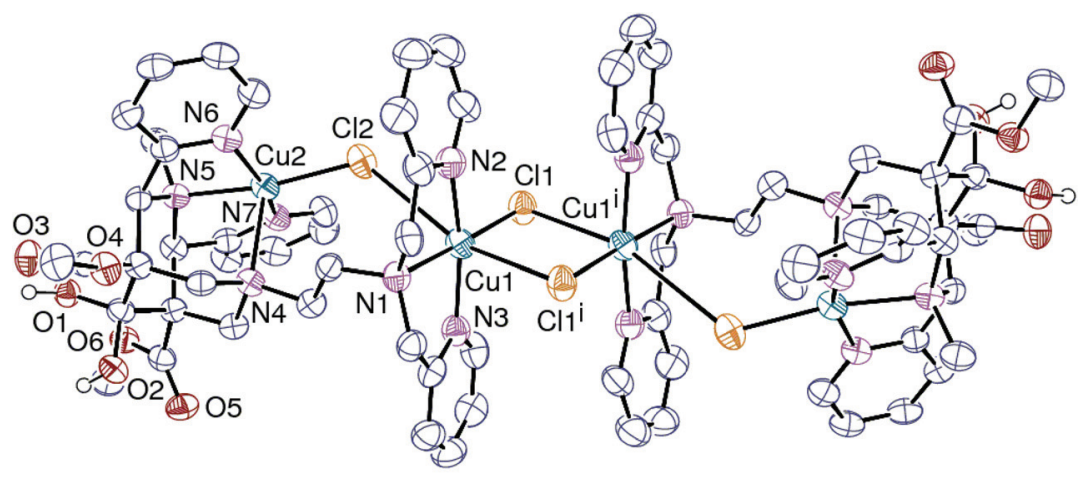

(a)

(b)

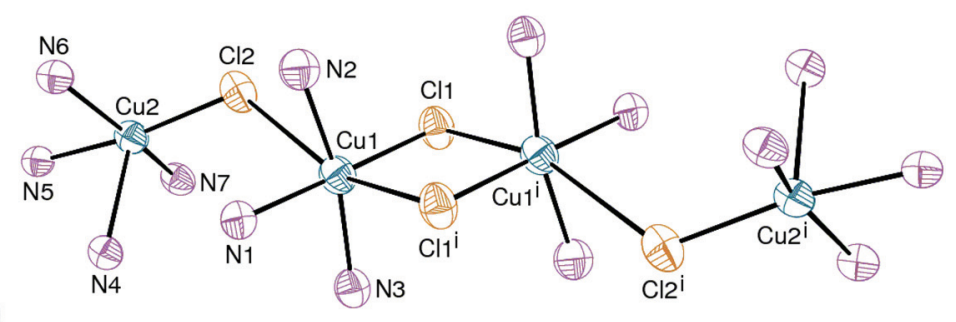

Fig. 2 (a) View of the centrosymmetric, cationic complex $\left[\mathrm{Cu}_{4} \mathrm{~L}_{2} \mathrm{Cl}_{4}\right]^{4+}$. Carbon-bound hydrogen atoms are omitted and displacement ellipsoids are drawn at the $50 \%$ probability level. Symmetry code: $i=1 / 2-x, 3 / 2-y,-z$. (b) View of the tetranuclear metal/donor atom array.

Table 1 Metal and donor atom geometry in $\left[\mathrm{Cu}_{4} \mathrm{~L}_{2} \mathrm{Cl}_{4}\right]\left(\mathrm{ClO}_{4}\right)_{4} \cdot 2 \mathrm{H}_{2} \mathrm{O}$

\begin{tabular}{llll}
\hline $\mathrm{Cu} 1-\mathrm{N} 1$ & $2.038(4) \AA$ & $\mathrm{Cu} 2-\mathrm{N} 4$ & $2.333(4) \AA$ \\
$\mathrm{Cu} 1-\mathrm{N} 2$ & $1.996(5) \AA$ & $\mathrm{Cu} 2-\mathrm{N} 5$ & $2.031(4) \AA$ \\
$\mathrm{Cu} 1-\mathrm{N} 3$ & $1.985(5) \AA$ & $\mathrm{Cu} 2-\mathrm{N} 6$ & $2.005(4) \AA$ \\
$\mathrm{Cu} 1-\mathrm{Cl} 1$ & $2.2514(14) \AA$ & $\mathrm{Cu} 2-\mathrm{N} 7$ & $1.990(4) \AA$ \\
$\mathrm{Cu} 1-\mathrm{Cl} 1{ }^{\mathrm{i}}$ & $2.8255(14) \AA$ & $\mathrm{Cu} 2-\mathrm{Cl} 2$ & $2.2097(14) \AA$ \\
$\mathrm{Cu} 1-\mathrm{Cl} 2$ & $3.2131(15) \AA$ & $\mathrm{Cu} 2 \cdots \mathrm{Cu} 1$ & $4.7889(9) \AA$ \\
$\mathrm{Cu} 1 \cdots \mathrm{Cu} 1^{\mathrm{i}}$ & $3.4919(12) \AA$ & &
\end{tabular}

Euler angles between plane 1 and plane 2:

$\begin{array}{lll}\mathrm{Cu} 1 \cdots \mathrm{Cu} 2 & 4.788 \AA & \alpha 48.57^{\circ}, \beta 75.25^{\circ}, \gamma 0.00^{\circ} \\ \mathrm{Cu} 1-\mathrm{Cl} 1-\mathrm{Cu} 1^{\mathrm{i}} & 86.13^{\circ} & \mathrm{Cu} 2-\mathrm{Cl} 2-\mathrm{Cu} 1\end{array}$

Symmetry code: $\mathrm{i}=1 / 2-x, 3 / 2-y,-z$.

ensure that there are no $\mathrm{Cu} \cdots \mathrm{Cu}$ contacts $\leq 10 \AA$ between sheets, and although there are inter-cation contacts spanning the anion-water sheets mediated by $\mathrm{CH} \cdots \mathrm{O}$ interactions of the bispidine ester groups, they are associated with a minimum $\mathrm{Cu}$... Cu distance just slightly $>13 \AA$ A. Thus, we assume that any intermolecular magnetic coupling would be limited to that within the cation sheets. Within a sheet, each $\mathrm{Cu}$ of a tetranuclear cation is separated by $b(=8.064 \AA)$ from the equivalent $\mathrm{Cu}$ of another and each terminal $\mathrm{Cu}$ is separated by $10.780 \AA$ from the terminal $\mathrm{Cu}$ atoms of two adjacent tetranuclear cations, this separation being shorter than that between the terminal $\mathrm{Cu}$ atoms $(12.823 \AA)$ of a given tetranuclear cation. Of course, it is expected that direct bridging of $\mathrm{Cu}$ centres by a ligand should give rise to a short separation and thus to the strongest coupling. As is commonly the case with $\mathrm{Cu}$ (II) complexes, there is some degree of arbitrariness in defining the coordination sphere of the metal. For each $\mathrm{Cu} 1$ atom, there are six donor atoms in proximity in an approximately octahedral (meridional $\mathrm{N}_{3} \mathrm{Cl}_{3}$ ) array, although the very long $\mathrm{Cu} 1 \cdots \mathrm{Cl} 2$ separation of $3.213 \AA$ indicates that the system is subject to a major Jahn-Teller distortion. The central $(\mathrm{Cu} 1)(\mathrm{Cl} 1)\left(\mathrm{Cu}^{i}\right)\left(\mathrm{Cl} 1^{i}\right)$ rhomb, in which $\mathrm{Cu} 1-\mathrm{Cl} 1=\mathrm{Cu} 1^{i}-\mathrm{Cl}^{i}=2.2514(14)$ and $\mathrm{Cu} 1-$ $\mathrm{Cl}^{i}=\mathrm{Cu}^{i}{ }^{i}-\mathrm{Cl} 1=2.8255(14) \AA$, is strictly planar with a Cu1...Cu1 distance of 3.4919(12) Å, geometrical characteristics which may, on the basis of comparison with known, simpler systems, ${ }^{6}$ be associated with ferromagnetic coupling of the $\mathrm{Cu}$ (II) centres (and a parallel arrangement of $\mathrm{d}_{z^{2}}$ orbitals in the approximation that $\mathrm{Cu} 1(\mathrm{~N} 1 \mathrm{~N} 2 \mathrm{~N} 3 \mathrm{Cl} 1)$ can be regarded as a square-planar unit). For each $\mathrm{Cu} 2$ atom, there are but five donor atoms in proximity, with the relatively long $\mathrm{Cu} 2-\mathrm{N} 4$ distance $(2.333(4) \AA)$ justifying the description of the $\mathrm{Cu} 2$ (N4N5N6N7Cl2) unit as a square pyramid with $\mathrm{N} 4$ in the axial position. While the square planar units incorporating $\mathrm{Cu} 1$ and $\mathrm{Cu} 1^{\prime}$ lie in parallel planes, this is not the case for the square planar units involving $\mathrm{Cu} 1$ and $\mathrm{Cu} 2$ (bridged by $\mathrm{Cl} 2$ ) (or $\mathrm{Cu} 1^{\mathrm{i}}$ and $\mathrm{Cu} 2^{\mathrm{i}}$, bridged by $\mathrm{Cl} 2^{\mathrm{i}}$ ), a situation which, in simpler systems, ${ }^{5}$ has been associated with ferromagnetic coupling of the metal centres, although the $\mathrm{Cu} 1 \cdots \mathrm{Cu} 2$ separation in the present complex is rather long (4.7881(9) §). Considering the ligand $\mathbf{L}$ alone, it behaves as an exclusively $\mathrm{N}$-donor, heptadentate species towards $\mathrm{Cu}$ (II) and is able to bind two such metal ions in quite close proximity, although the flexibility in the link between the $\mathrm{N}_{4}$ and $\mathrm{N}_{1}$ donor sites presumably means that the juxtapositioning of the complexed units could be sensitive to the nature of other ligands (here, chloride) involved.

\section{Magnetism}

The magnetic susceptibility of powdered crystals was measured at 500 Oe in the range of 2 to $300 \mathrm{~K}$. At room temperature the 
$\chi T$ value is $1.40 \mathrm{~cm}^{3} \mathrm{~K} \mathrm{~mol}^{-1}$, which corresponds to four uncoupled $\mathrm{Cu}(\mathrm{II})$ centres with $S=0.5$ each. The maximum susceptibility is reached at $5 \mathrm{~K}$ with a $\chi T$ value of $1.91 \mathrm{~cm}^{3} \mathrm{~K}$ $\mathrm{mol}^{-1}$. This fits a system of two ferromagnetically coupled $\mathrm{Cu}$ (II) ions $\left(S_{\text {total }}=1\right)$ and two additional uncoupled $\mathrm{Cu}$ (II) centres $(2 \times S=0.5)$. This is also what one can expect from the molecular structure of the tetrakis-copper(II) complex with angles between the two central $\mathrm{Cu}$ (II) ions and the two bridging chlorides ( $\mathrm{Cl} 1$ and $\mathrm{Cl}^{\mathrm{i}}$ ) of close to $90^{\circ}$, i.e., this is a geometric arrangement known to lead to ferromagnetic coupling. ${ }^{15}$ The decrease of $\chi T$ below $5 \mathrm{~K}$ indicates an antiferromagnetic coupling pathway between the inner and the outer $\mathrm{Cu}$ (II) ions at these temperatures. This is supported by a qualitative fit of the data, which suggests that the coupling between the weakly coupled outer copper(II) centres (Cu1 and $\mathrm{Cu} 2$ ) is $J_{1}=-0.1 \mathrm{~cm}^{-1}$, and the stronger coupled central pair of $\mathrm{Cu}$ (II) ions have $J_{2}=5 \mathrm{~cm}^{-1}$ (see ESI $\dagger$ ). Note that only a relatively small amount of the crystalline sample used for crystallography was available, and all experiments were done with this sample for consistency of the data. The scattering observed in the susceptibility data is due to the small quantity of material available and, therefore, these data have only been interpreted qualitatively.

The magnetization was measured at $2 \mathrm{~K}$ and $5 \mathrm{~K}$ at fields between 0 and 5 T (Fig. 3). For each temperature three Brillouin functions are plotted, and those with a ferromagnetically coupled inner pair and two uncoupled outer $\mathrm{Cu}$ (II) ions (blue curves), i.e. those which qualitatively agree with the above interpretation, fit the experimental data reasonably well.

\section{EPR spectroscopy}

EPR spectra were measured from solid samples (powder) and from frozen solutions. Powder spectra were measured at room temperature, those from glasses ( $1 \mathrm{mM}$ solutions in $\mathrm{MeOH})$ at 110 K. Due to magnetic interactions between the tetranuclear units in the crystal lattice, the solid state spectra were, as expected, rather unstructured (see $\mathrm{ESI}_{\dagger}^{\dagger}$ ). In $\mathrm{MeOH}$, which was used as the solvent for the frozen solution spectra, dissociation of the axial chloride ligands $\mathrm{Cl}^{\mathrm{i}}$ may lead to dinuclear species with partially differing structures if the tenuous interaction $\mathrm{Cu} 1-\mathrm{Cl} 2$ is also replaced by one with a solvent. Indeed, the experimental spectra are typical for mononuclear $\mathrm{Cu}$ (II) complexes (Fig. 4).

The simulation of this spectrum shown in Fig. $4 \mathrm{~b}$ reveals spin Hamiltonian parameters typical for a mononuclear axial $\mathrm{Cu}(\mathrm{II})$ site. However, a comparison of the experimental and simulated spectra reveals that there are additional features, and these are visualized in Fig. 4c, which is a difference spectrum involving the experimental and simulated traces. Indeed, there are also very weak signals at half-field, typical for forbidden $\Delta m_{\mathrm{J}}= \pm 2$ transitions of dinuclear Cu(II) complexes (Fig. $4 \mathrm{a}$; this part of the spectrum is plotted with a larger amplitude).

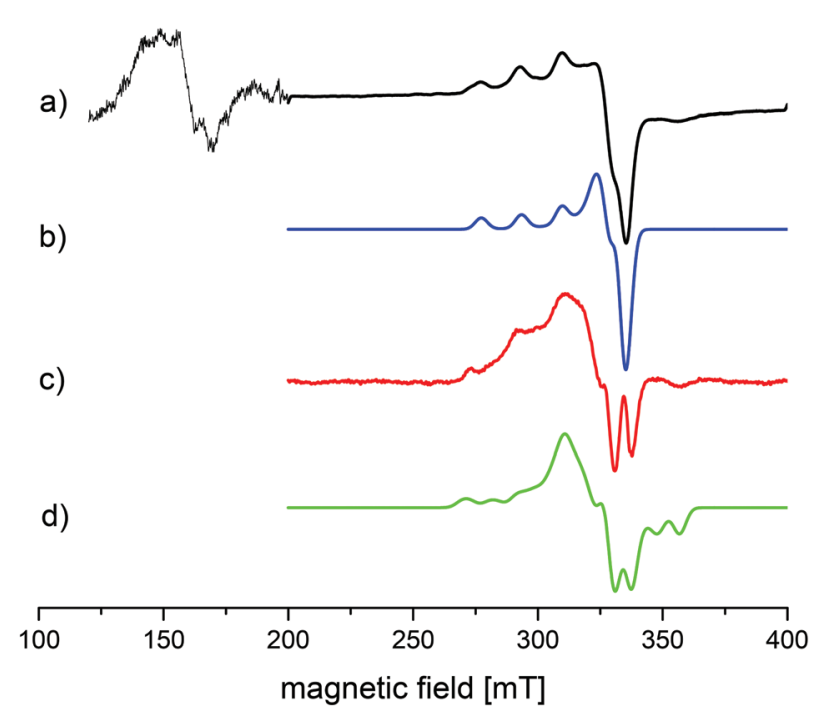

Fig. 4 (a) EPR spectrum measured in $\mathrm{MeOH}(1 \mathrm{mM})$ at $110 \mathrm{~K}$ (black line), (b) simulated spectrum (blue line): $9.43671 \mathrm{GHz} ; g_{x}=2.044, g_{y}=2.068$, $g_{z}=2.238 ; A_{x}=16.1, A_{y}=17.2, A_{z}=168.8\left[10^{-4} \mathrm{~cm}^{-1}\right]$, (c) difference spectrum of (a) and (b) (red line) and (d) simulation using dipole-dipole coupling between the Cu1 and Cu2 centres (green line): $9.43671 \mathrm{GHz}$; Cu1: $g_{x}=2.034, g_{y}=2.056, g_{z}=2.262 ; A_{x}=15, A_{y}=15, A_{z}=115 ;$ Cu2: $g_{x}=1.922, g_{y}=2.112, g_{z}=2.237 ; A_{x}=6, A_{y}=6, A_{z}=112\left[10^{-4} \mathrm{~cm}^{-1}\right]$.
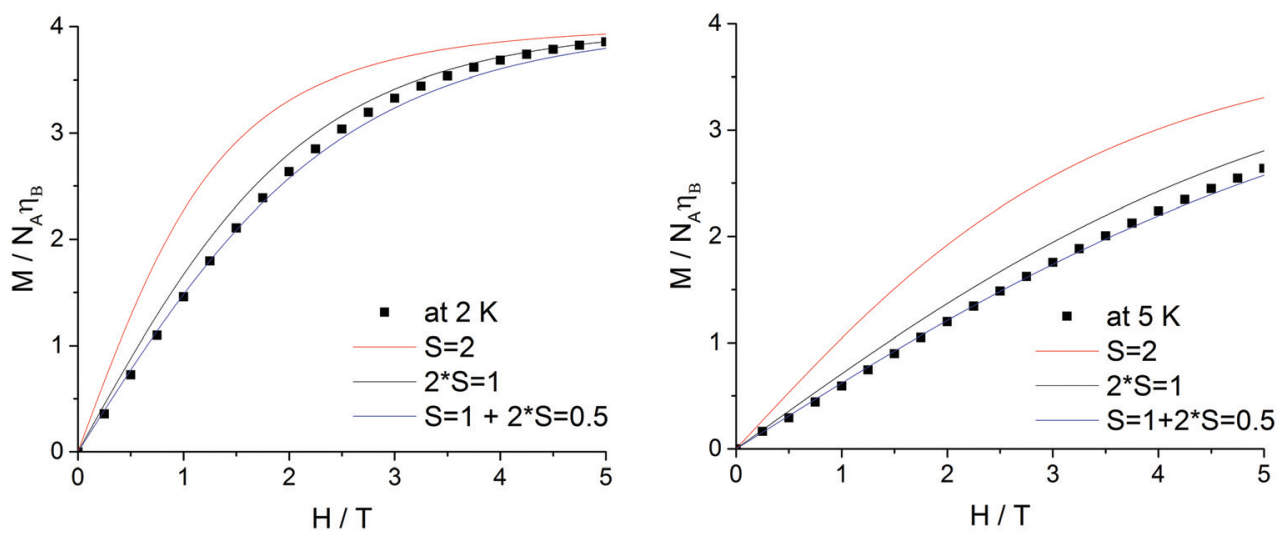

Fig. 3 Magnetisation vs. field at $2 \mathrm{~K}$ (left) and $5 \mathrm{~K}$ (right); three curves are plotted together with the experimental data (black squares), i.e. for systems with either a total spin of 2 (for ferromagnetically coupled $\mathrm{Cu}(I)$ centres, red line), or two uncoupled centres with a spin of 1 each (black line), or one ferromagnetically coupled pair of $\mathrm{Cu}(I)$ centres with a total spin of 1 plus two other $\mathrm{Cu}(I)$ centres with a spin of 0.5 each (blue line). 
The simulation of dipole-dipole coupled spectra of dicopper(II) complexes may be used for solution structural assignments. ${ }^{16,17}$ The simulation of the $\Delta m_{\mathrm{J}}= \pm 1$ transitions (Fig. $4 \mathrm{~d}$; structural parameters together with the spin Hamiltonian parameter are given in the figure caption, see also Table 1) indicates that there is some structural rearrangement of the dinuclear subunits, and this may be due to dissociation of the chlorido bridges. We therefore conclude that there are (at least) two conformations of the dinuclear subunits, with different orientations (and distances) of the two $\mathrm{Cu}^{\mathrm{II}}$ centres (Cu1 and $\mathrm{Cu} 2$ ), one leading to a weak dipole-dipole coupling, and one to an uncoupled system (or a situation governed by "magic angles"). ${ }^{18}$

\section{Conclusions}

The $\mathrm{N}_{7}$-donor ligand $\mathbf{L}$ characterized in the present work, while providing chelating sites which can strongly bind two $\mathrm{Cu}$ (II) centres, at the same time leaves open access to coordination sites which enable a simple bridging ligand like the chloride ion to cause the formation of extended magnetic aggregates. The ligand superstructure is, however, effective in limiting $\mathrm{Cu} \cdots \mathrm{Cl}$ interactions within the dinuclear unit involving one ligand to much weaker antiferromagnetic interactions than the ferromagnetic interactions resulting from chloride bridging between dinuclear units.

\section{Acknowledgements}

This research was supported by the Basic Science Research Program of the National Research Foundation of Korea (NRF) funded by Korean Ministry of Education (2011-0011187).

\section{References}

1 (a) H. Börzel, P. Comba, K. S. Hagen, M. Kerscher, H. Pritzkow, M. Schatz, S. Schindler and O. Walter, Inorg. Chem., 2002, 41, 5440; (b) P. Comba, M. Kerscher and W. Schiek, Prog. Inorg. Chem., 2008, 55, 613-704 (ch. 9); (c) C. Busche, P. Comba, A. Mayboroda and H. Wadepohl, Eur. J. Inorg. Chem., 2010, 1295-1302.

2 (a) P. Comba, B. Martin, A. Muruganantham and J. Straub, Inorg. Chem., 2012, 51, 9214-9225 and references therein; (b) P. Comba, N. Dovalil, L. R. Gahan, G. R. Hanson and M. Westphal, Dalton Trans., 2014, 43, 1935-1956.

3 (a) M. Atanasov, P. Comba, G. R. Hanson, S. Hausberg, S. Helmle and H. Wadepohl, Inorg. Chem., 2011, 50, 6890-
6901; (b) M. Atanasov, P. Comba and S. Helmle, Inorg. Chem., 2012, 51, 9357-9368; (c) M. Atanasov, P. Comba, S. Helmle, D. Müller and F. Neese, Inorg. Chem., 2012, 51, 12324-12335.

4 (a) B. Bleaney and K. D. Bowers, Proc. Roy. Soc. (London) A, 1952, 214, 451-465; (b) M. Kato, H. B. Jonassen and J. C. Fanning, Chem. Rev., 1964, 64, 99-128; (c) R. H. Holm, P. Kennepohl and E. I. Solomon, Chem. Rev., 1996, 96, 2239-2314.

5 See, for example: S. Thakurta, P. Roy, G. Rosair, C. J. Gomez-Garcia, E. Garribba and S. Mitra, Polyhedron, 2009, 28, 695-702 and references therein.

6 (a) W. E. Marsh, K. C. Patel, W. E. Hatfield and D. J. Hodgson, Inorg. Chem., 1983, 22, 511-515; (b) W. A. Alves, R. H. de Almeida-Santos, A. Paduan-Filho, C. C. Becerra, A. C. Borin and A. M. Da Costa Ferreira, Inorg. Chim. Acta, 2004, 357, 2269-2278.

7 (a) H. Börzel, P. Comba, K. S. Hagen, C. Katsichtis and H. Pritzkow, Chem.-Eur. J., 2000, 6, 914-919; (b) G. S. Matouzenko, A. Bousseksou, S. Lecocq, P. J. van Koningsbruggen, M. Perrin, O. Kahn and A. Collet, Inorg. Chem., 1997, 36, 2975-2981; (c) W. J. Wilhelm, J. Org. Chem., 1952, 17, 523-528.

8 (a) P. Comba, M. Merz and H. Pritzkow, Eur. J. Inorg. Chem., 2003, 1711-1718; (b) U. Holzgrabe and E. Ericyas, Arch. Pharm., 1992, 325, 657.

9 R. W. W. Hooft, COLLECT, Nonius BV, Delft, The Netherlands, 1998.

10 Z. Otwinowski and W. Minor, Methods Enzymol., 1997, 276, 307-326.

11 G. M. Sheldrick, Acta Crystallogr., Sect. A: Fundam. Crystallogr., 2008, 64, 112-122.

12 G. R. Hanson, K. E. Gates, C. J. Noble, M. Griffin, A. Mitchell and S. Benson, J. Inorg. Biochem., 2004, 98, 903-916.

13 (a) P. Pascal, A. Pacault and J. C. R. Hoarau, Comptes Rendus Acad. Sci., 1951, 233, 1078; (b) G. A. Bain and J. F. Berry, J. Chem. Educ., 2008, 85, 532-536.

14 E. Bill, julX, Max-Planck Institute of Bioinorganic Chemistry, MPI für Bioanorganische Chemie, Mülheim, Germany; http://ewww.mpi-muelheim.mpg.de/bac/logins/ bill/juIX_en.php

15 O. Kahn, Molecular Magnetism, John Wiley \& Sons Inc., New York, 1993.

16 J. R. Pilbrow and T. D. Smith, Coord. Chem. Rev., 1974, 13, 173-278.

17 P. V. Bernhardt, P. Comba, T. W. Hambley, S. S. Massoud and S. Stebler, Inorg. Chem., 1992, 31, 2644-2651.

18 P. Comba, N. Dovalil, G. R. Hanson and G. Linti, Inorg. Chem., 2011, 50, 5165-5174. 